\title{
CAVE HYGROPETRIC BEETLES AND THEIR FEEDING BEHAVIOUR, A COMPARATIVE STUDY OF CANSILIELLA SERVADEII AND HADESIA ASAMO (COLEOPTERA, LEIODIDAE, CHOLEVINAE, LEPTODIRINI)
}

\author{
PRIMERJAVA JAMSKIH HIGROPETRIČNIH HROŠČEV IN NJIHOVEGA \\ PREHRANJEVANJA; CANSILIELLA SERVADEII IN HADESIA ASAMO \\ (COLEOPTERA, LEIODIDAE, CHOLEVINAE, LEPTODIRINI)
}

\begin{abstract}
Luca DORIGO ${ }^{1, *}$, Andrea SQUARTINI ${ }^{2}$, Vladimiro TONIELLO ${ }^{3}$, Angelo Leandro DREON ${ }^{4}$, Alberto PAMIO ${ }^{5}$, Giorgio CONCINA ${ }^{6}$, Venicio SIMONUTTI ${ }^{7}$, Enrico RUZZIER ${ }^{8}$, Michel PERREAU ${ }^{9}$, Annette Summers ENGEL ${ }^{10}$, Federico GAVINELLI ${ }^{11}$, Isabel MARTINEZ-SANUUDO ${ }^{12}$, Luca MAZZON ${ }^{13} \&$ Maurizio G. PAOLETTI ${ }^{14}$
\end{abstract}

\begin{abstract}
UDC 595.76:591.5

Luca Dorigo, Andrea Squartini, Vladimiro Toniello, Angelo Leandro Dreon, Alberto Pamio, Giorgio Concina, Venicio Simonutti, Enrico Ruzzier, Michel Perreau, Annette Summers Engel, Federico Gavinelli, Isabel Martinez-Sañudo, Luca Mazzon \& Maurizio G. Paoletti: Cave hygropetric beetles and their feeding behaviour, a comparative study of Cansiliella servadeii AND Hadesia asamo (Coleoptera, Leiodidae, Cholevinae, Leptodirini)

Several Leptodirini beetles (Leiodidae) are known to dwell in hygropetric habitats where films of water run down the cave walls, but observations of their behaviour are lacking. The ultra-specialised hygropetricolous beetles belonging to the genera Cansiliella and Hadesia are biogeographically and phylogenetically unrelated leptodirines. As the species of the former
\end{abstract}

\begin{abstract}
Izvleček
UDK 595.76:591.5

Luca Dorigo, Andrea Squartini, Vladimiro Toniello, Angelo Leandro Dreon, Alberto Pamio, Giorgio Concina, Venicio Simonutti, Enrico Ruzzier, Michel Perreau, Annette Summers Engel, Federico Gavinelli, Isabel Martinez-Sañudo, Luca Mazzon \& Maurizio G. Paoletti: Primerjava jamskih higropetričnih hroščev in njihovega prehranjevanja; Cansiliella servadeii in Hadesia asamo (Coleoptera, Leiodidae, Cholevinae, Leptodirini)

Številni hrošči iz poddružine Leptodirinae (Leiodidae) so prilagojeni na življenje v posebnem habitatu »jamskem higropetriku«, t.j. tankem sloju tekoče vode, ki teče po sigi. Zaenkrat je njihovo vedenje še precejšnja neznanka. Visoko specializirani higropetrični vrsti Cansiliella servadeii in Hadesia asamo sta geografsko ločeni in filogenetsko nesorodni. Ker je prva
\end{abstract}

\footnotetext{
${ }^{1}$ Luca Dorigo, Museo Friulano di Storia Naturale, via Sabbadini 32, 33100 Udine, Italy, e-mail: luca.dorigo1979@gmail.com

${ }^{2}$ Andrea Squartini, Dipartimento di Biotecnologie Agrarie, Università di Padova, Legnaro (PD), Italy, e-mail: squart@unipd.it

${ }^{3}$ Vladimiro Toniello, Gruppo Speleologico C.A.I. di Vittorio Veneto (TV), Italy, e-mail: vladimiro.toniello@virgilio.it

${ }^{4}$ Angelo Leandro Dreon, Dipartimento di Biologia, Università di Padova, Agroecology and Ethnobiology, Padova, Italy, e-mail: leandro.dreon@libero.it

${ }^{5}$ Alberto Pamio, Dipartimento di Biologia, Università di Padova, Agroecology and Ethnobiology, Padova, Italy, e-mail: albertopamio@gmail.com

${ }^{6}$ Giorgio Concina, Gruppo Speleologico Pradis, Clauzetto (PN), Italy, e-mail: g.concina@libero.it

${ }^{7}$ Venicio Simonutti, Gruppo Speleologico Pradis, Clauzetto (PN), Italy, e-mail: veniciosimonutti@alice.it

${ }^{8}$ Enrico Ruzzier, The Natural History Museum, London, UK, e-mail: symphyla@gmail.com

${ }^{9}$ Michel Perreau, IUT Paris Diderot, Université Paris Diderot, Sorbonne Paris Cité, France, e-mail: michel.perreau@univ-parisdiderot.fr

${ }^{10}$ Annette Summers Engel, Department of Earth and Planetary Sciences, University of Tennessee, Knoxville, Tennessee, USA, e-mail: aengel1@utk.edu

${ }^{11}$ Federico Gavinelli, Dipartimento di Biologia, Università di Padova, Agroecology and Ethnobiology, Padova, Italy, e-mail: federico.gavinelli@gmail.com

${ }^{12}$ Isabel Martinez-Sañudo, Dipartimento di Agronomia Animali Alimenti Risorse Naturali e Ambiente, Università di Padova Agripolis, Legnaro (PD), Italy, e-mail: isabel.martinez@unipd.it

${ }^{13}$ Luca Mazzon, Dipartimento di Agronomia Animali Alimenti Risorse Naturali e Ambiente, Università di Padova - Agripolis, Legnaro (PD), Italy, e-mail: lmazzon@unipd.it

${ }^{14^{*}}$ Maurizio G. Paoletti, Dipartimento di Biologia, Università di Padova, Agroecology and Ethnobiology, Padova, Italy, e-mail: paoletti@bio.unipd.it

* Corresponding Author
}

Received/Prejeto: 08.02.2017 
genus are known to be associated with the moonmilk deposits our study aimed to obtain data on their foraging behaviour, as well as to compare the feeding strategies of both genera. In situ monitoring of $C$. servadeii from the cave Grotta della Foos (Italy) and $H$. asamo from Bravenik Cave (Bosnia and Herzegovina), was complemented by video recordings to ensure accurate results. Mouthparts and tarsi of both species were examined using scanning electron microscopy and compared with $H$. weiratheri from Montenegro to evaluate potential morphological adaptations to the hygropetricolous ecological niches. The three species had significantly different mouthpart morphologies, likely due to differences in semi-aquatic feeding strategies and overall ecology. A series of new observations on site movement and feeding behaviour are presented, compared and discussed.

Key words: Coleoptera, ecology, behaviour, moonmilk, cave hygropetric. očitno vezana na depozite mehke sige (t.i. jamsko mleko), smo želeli raziskati iskanje hrane pri tej vrsti ter primerjati strategijo hranjenja obeh vrst. Da bi povečali zanesljivost rezultatov, smo poleg in situ opazovanja C. servadeii iz jame Grotta della Foos (Italija) in H. asamo iz jame Bravenik (Bosna in Hercegovina), njuno vedenje tudi posneli. $Z$ vrstičnim elektronskim mikroskopom smo raziskali obustne okončine in stopalca obeh vrst in jih primerjali s $H$. weiratheri iz Črne gore, da bi preverili potencialne morfološke prilagoditve na specifično ekološko nišo. Bistvene razlike $\mathrm{v}$ zgradbi ustnega aparata so najverjetneje posledica razlik v strategiji hranjenja, kot tudi različne splošne ekologije omenjenih vrst. V prispevku predstavljamo, primerjamo in razpravljamo o novih opažanjih povezanih $\mathrm{Z}$ gibanjem in prehranjevanjem higropetričnih hroščev.

Ključne besede: Coleoptera, ekologija, vedenje, jamsko mleko, jamski higropetrik.

\section{INTRODUCTION}

The buccal apparatus (mouthparts) of some highly specialised subterranean Leptodirini differs considerably in shape and structure with respect to what is observed in other tribe members. In some species, this fact has been interpreted as a result of an adaptation to a semiaquatic trophic niche (Paoletti 1972; Casale et al. 2000a; Moldovan et al. 2004). In several unrelated species from eight genera (out of 235 globally described, unpublished data), ultra-specialized ecomorphological forms have evolved, including in Hadesia Müller, 1911; Croatodirus Casale, Giachino \& Jalžić, 2000; Nauticiella Moravec \& Mlejnek, 2002; Velebitodromus Casale, Giachino \& Jalžić, 2004; Kircheria Giachino \& Vailati, 2006 (subtribe Anthroherponina Jeannel); Radziella Casale \& Jalžić, 1988 (subtribe Leptodirina Lacordaire); Cansiliella Paoletti, 1972 and Tartariella Nonveiller \& Pavićević, 1999 (subtribe Bathysciina Horn). All of these leptodirines are distributed in the North-Eastern sector of the Italian Alps and in the Dinaric Alps, and share a similar semi-aquatic cave habitat, described originally by Remy (1940) and formally defined by Sket $(1979,2004)$ as "cave hygropetric". As such, the distribution of the hygropetricolous leptodirines has been linked to areas with high annual precipitation at high altitudes (see, i.e., Fig. 33 in Giachino \& Vailati 2006). Some species have been observed only in periods of considerable rainfall (Perreau \& Pavićević 2008). Leptodirini can show highly modified mouthparts. The mandibles are hoe-shaped and the galeae have a spoon shape (e.g., Fig. 4, 4 in Paoletti et al. 2011). The galeae are also covered by dense, bristly structures on the dorsal side (Paoletti 1972, 1973; Casale \& Jalžić 1988; Moldovan et al. 2004; Paoletti et al. 2011, 2013; Lo- haj et al. 2012; Engel et al. 2013). Modified mouthparts (i.e., the presence of setae, the rotation of the apex of the mandibles), described by Jeannel (1924), Remy (1940), Nonveiller and Pavićević (1999), Moravec and Mlejnek (2002), Perreau and Pavićević (2008) and Polak et al. (2016), have been referred to as "filtering mouthparts" (Casale et al. 2000a; Casale et al. 2000b; Casale et al. 2004; Moldovan et al. 2004) or "brushing mouthparts" (Perreau \& Pavićević 2008).

The physiological and behavioural adaptations, as well as migration through the subterranean habitat, have been studied in only a few obligate cave inhabitants (Kane \& Poulson 1976; Culver 1982; Lamprecht \& Weber 1992; Rétaux \& Elipota 2013). In general, the activities of cave organisms, predominantly invertebrates, are scarcely known, except for cases that appear as unique within cave fauna. For example, the feeding and foraging behaviour of Cansiliella servadeii Paoletti, 1980 was noteworthy because this species is not attracted by baits, nor has it been observed on deposits of guano or organic matter, but the species is found in association with moonmilk deposits (Paoletti et al. 2011). Moonmilk is a whitish, porous speleothem characterized by a soft texture (Hill \& Forti 1997) that is usually permanently covered by percolating water and has a rich microbial biomass. The moonmilk microbiology, the digestive tract contents of several beetle individuals, and mouthpart morphology have been previously studied (Paoletti et al. 2011, 2012, 2013; Engel et al. 2013).

For this study, our aims were to uncover the trophic ecology of C. servadeii by obtaining accurate temporal data on behavioural activities and to compare the 
feeding and foraging strategy of the species with those evolved in other cave hygropetricolous leptodirines, including Hadesia asamo Perreau \& Pavićević, 2008, and Hadesia weiratheri Zariquiey, 1927. In addition to behavioural observations, microscopic examination of mouthparts and other body traits was done in C. servadeii, $H$. asamo and $\mathrm{H}$. weiratheri. Collectively, these results provide important information on the behavioural biology of biogeographically and phylogenetically unrelated hygropetricolous beetles. The implications of this research also extend broadly to beetle ecology, particularly with respect to the relationship between morphological adaptation and occupation of different ecological niches in a similar habitat. Although additional observational data will be needed for verification, our findings may be extrapolated to other species of both genera, i.e., Cansiliella tonielloi Paoletti, 1972, C. montisceseni Piva, 2000, and Hadesia vasiceki Müller, 1911, H. lakotai Perreau \& Pavićević, 2008, and H. zetae Delić, Polak \& Trontelj, 2016.

\section{MATERIALS AND METHODS}

The is only known locality for C. servadeii is the cave Grotta della Foos (507/229 FR) (total length $2625 \mathrm{~m}$, total depth $161 \mathrm{~m})$, in Tramonti di Sotto (PN), Carnic Prealps, northeastern Italy. Observation sites were chosen where at least two to three individuals per square meter were found. Sites were marked with flags and photographed.

Each observation session for each beetle lasted six hours per researcher. Individual beetles under observation were pointed at to the next-shift researcher at the end of an observation period to guarantee continued data recording of the same beetle during the long-term tracking. Using this approach, the same individuals were monitored by different observers in 24-h sessions. Individuals were observed at close distance and were illuminated by a cold LED light to avoid heat-related disturbance. In order to appreciate the details of the trophic and cleaning activities, and to identify the sex of the beetles, a 30X magnifying lens was used. Sex determination in C. servadeii was possible due to external morphological sexual dimorphism. Beetle behaviour was recorded on a standardized data collection form prepared before sampling and based on prior observations (Paoletti et al. 2011). Photographs and video were also taken with a 550D Canon camera. Each behavioural activity lasting more than $1 \mathrm{~min}$, as well as shorter activities that were considered significant, were recorded.

To simplify the recording process, five different behavioural categories were distinguished: trophic activity, cleaning or preening, site movement, interaction with other individuals, and other activities. As a trophic activity, the action of a beetle, with head facing down, in contact with the substrate, moving jaws and galeae and seemingly browsing the moonmilk surface was considered. Cleaning was denoted by a repeated preening action, or rubbing legs and antennae against mouthparts. This behaviour is always accompanied by movement of jaws and galeae. For every movement of the individual on the substrate, we noted moving and recorded direction, distance travelled, and any other possible type of movements. Interaction was recorded in the presence of conspecifics. Lastly, other activities were considered as any behaviour that did not fall under the prior four categories. Anomalous behaviours were recorded for further investigation. The amount of time spent within and outside of the water film during activities was also recorded.

Hadesia asamo is known from a single pit called Bravenik Cave (total length $225 \mathrm{~m}$, total depth $200 \mathrm{~m}$ ) at $800 \mathrm{~m}$ a.s.l. in the Zubačko Polje, about $10 \mathrm{~km}$ from Trebinje (Perreau \& Pavićević 2008), and H. weiratheri was collected from an unnamed pit near Ledenice, Kameno more, Montenegro. Behaviour observations of three $H$. asamo individuals were done, one of them was filmed with a 550D Canon camera for $40 \mathrm{~min}$ with cold LED light to avoid any heat-related stress. No behavioural observations were possible in $H$. weiratheri, it was only used for morphological comparisons. As already reported in Perreau and Pavićević (2008), the presence of Hadesia spp. has been strongly correlated to the water flow rate and, in general, only a few individuals can usually be seen during cave expeditions.

In the caves, conductivity, temperature, $\mathrm{pH}$, and oxygen level in the water, were recorded in situ with a standard HACH portable sensION ${ }^{\mathrm{TM}} 156$ Multiparameter Meter calibrated at $20{ }^{\circ} \mathrm{C}$. Electrical conductivity was measured following APAT CNR IRSA 2030 Man 29 2003 method, total hardness according to APAT CNR IRSA 2040 A Man 292003 method, and ammonia-nitrogen following APAT CNR IRSA 4030 A2 Man 292003 method. Anions were detected according to EPA 9056 A 2007 method and cations according to EPA 6020 B 2014, with the chromatographic instruments CS-1600+ HPLC Dionex and CS-2000+ HPLC Dionex from Thermo Sci- 
entific. The metal composition of substrate, including moonmilk, was detected with atomic absorption spectrophotometry using a graphite cooker SMEWW 3113 B (APHA 2012).
Mouthparts and tarsal segments of C. servadeii, $H$. asamo, and $H$. weiratheri were prepared and compared using a scanning electron microscope (SEM), using methods as described by Paoletti et al. (2011).

\section{RESULTS}

\section{OBSERVATIONS OF BEHAVIOUR}

Video footage for Cansiliella and Hadesia is available at https://www.youtube.com/watch?v=hWNkAiArSwk\&fe ature=youtu.be.

Cansiliella. The population size of C. servadeii is currently unknown. All individuals were observed in a part of the cave named "Cavernone" (sensu Gasparo 1971) where extensive moonmilk deposits exist and water flows over the deposits (Paoletti et al. 2011). In a single observation session, a maximum of 83 individuals were counted, with a maximum density of 8 individuals per $\mathrm{m}^{2}$ of moonmilk deposit. During the year, the amount of water flowing at the sampling site did not significantly change and aqueous conditions were constant. The air temperature of the "Cavernone" was $8.6^{\circ} \mathrm{C}$, humidity reached saturation, and the water temperature was $8.8^{\circ} \mathrm{C}$. Tab. 1 lists the water and moonmilk physicochemical properties in the caves where Cansiliella and Hadesia were present.

The behaviour and activities of eight $C$. servadeii individuals were continuously monitored for 1826 minutes (Tab. 2; Fig. 1). Individuals, which were 2.6 to $3.0 \mathrm{~mm}$ long, were mainly observed in areas covered by moonmilk and not on moist, bare rock.

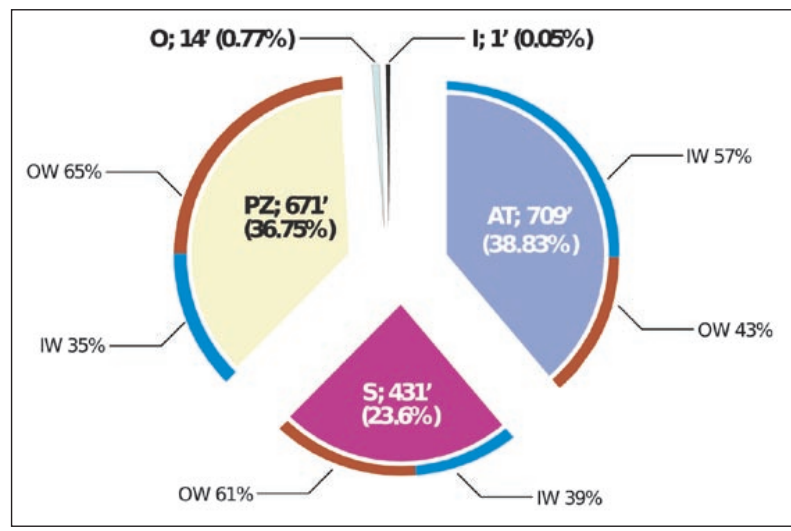

Fig. 1: Proportions of the activity types for all observed Cansiliella servadeii in 24-hour observation. Activities are annotated as: AT, trophic activity; S, site movement; PZ, cleaning of legs (and antennae); $O$, other activities; I, interaction with other individuals; IW, activity performed in water; OW, activity performed out of water.
Although there was behavioural variability among individuals, beetles spent as much as $75 \%$ of their time on trophic activities (i.e., feeding and foraging) and preening legs and antennae.

For all C. servadeii except individual "E," which did not exhibit any feeding or foraging trophic activities (Tab. 2), trophic activity lasted on average $39 \%$ of the observation time, and was performed in and out of water (57 \% and $43 \%$, respectively). During immersion, a bubble of air was constantly present and covered the beetle (Fig. 2, top row), as previously reported (Paoletti et al. 2011). Often, individuals moved from moist surfaces to areas with flowing water that was up to $4 \mathrm{~cm}$ deep. Sloped moonmilk surfaces appeared to be preferred to flat surfaces. In overall, movement represented just under a quarter $(23.6 \%)$ of the observation time, with distances ranging from less than $1 \mathrm{~cm} / \mathrm{min}$ to $11 \mathrm{~cm} / \mathrm{min}$, with individuals often moving within the water film. All individuals were observed on moonmilk, inside or outside the water film. Only individual " $D$ " moved over bare rock without any trophic or preening activities for eleven minutes before returning to moonmilk. Preening activity varied by individual, representing (on average) up to $36 \%$ of the observation time. Individual "N" did not show any cleaning activity, whereas individual "V" spent $78 \%$ of the time preening (Tab. 2). A case of conspecific interaction was also observed: a female (individual "D") approached another female ("E"), and when they touched with antennae, "D" immediately turned around and left the area.

Hadesia. Behaviour of three H. asamo individuals, from 7.3 to $8.0 \mathrm{~mm}$ long, was observed and videorecorded for about 40 minutes, while the assessment of the activity changes over time (as in C. servadeii) has not been possible. The cave inhabited by $H$. asamo mostly lacks moonmilk deposits, and where they are present, deposits only constitute a very thin layer. H. asamo individuals moved actively and quickly on bare rock or/ and on compact carbonate concretions. When they approached water, they turned their abdomen against the water flow (Fig. 2, bottom row), as if to collect organic particles transported by water. An individual was observed standing with body trunk above a stream of water 
CAVE HYGROPETRIC BEETLES AND THEIR FEEDING BEHAVIOUR, A COMPARATIVE STUDY OF CANSILIELLA SERVADEII ...

Tab. 1: Chemical and physical characteristics of percolating waters in karst caves hosting Cansiliella spp. and Hadesia asamo.

\begin{tabular}{|c|c|c|c|c|c|c|}
\hline Locality & $\begin{array}{l}\text { GROTTA } \\
\text { DELLA FOOS } \\
\text { CAVE Friuli, } \\
\text { Italy }\end{array}$ & $\begin{array}{l}\text { BUS DELLA } \\
\text { GENZIANA } \\
\text { CAVE Friuli, } \\
\text { Italy }\end{array}$ & $\begin{array}{l}\text { BUS DELLA } \\
\text { GENZIANA } \\
\text { CAVE Friuli, } \\
\text { Italy }\end{array}$ & $\begin{array}{l}\text { BRAVENIK CAVE } \\
\text { Bosnia and } \\
\text { Herzegovine }\end{array}$ & $\begin{array}{l}\text { VECCHIA DIGA } \\
\text { CAVE Friuli, } \\
\text { Italy }\end{array}$ & $\begin{array}{l}\text { MCL CAVE Friuli } \\
\text { Italy }\end{array}$ \\
\hline Cave entrance ( $m$ a.s.l.) & 422 & 1020 & 1020 & 800 & 483 & 970 \\
\hline Date of Measurement & \begin{tabular}{|l}
$2008-2010$ \\
Average \\
values
\end{tabular} & $\begin{array}{l}01 / 01 / 2009 \\
\text { Measured Value }\end{array}$ & $\begin{array}{l}01 / 06 / 2010 \\
\text { Measured } \\
\text { Value }\end{array}$ & $\begin{array}{l}\text { 03/07/2011 } \\
\text { Measured Value }\end{array}$ & $\begin{array}{l}\text { 01/10/2009 } \\
\text { Measured } \\
\text { Value }\end{array}$ & $\begin{array}{l}\text { 24/10/2015 } \\
\text { Measured Value }\end{array}$ \\
\hline \multicolumn{7}{|l|}{ Mesured Parameters } \\
\hline Air temperature $\left({ }^{\circ} \mathrm{C}\right)$ & 8.60 & $6 . .2$ & & & 7.3 & 6.4 \\
\hline Water temperature $\left({ }^{\circ} \mathrm{C}\right)$ & 8.80 & 7.0 & & & 8.8 & 6.6 \\
\hline Relative Humidity & $100 \%$ & $100 \%$ & & & $100 \%$ & $100 \%$ \\
\hline Oxygen dissolved (mg/L) & 10.27 & 7.87 & & 10.8 & 8.08 & 11.56 \\
\hline $\mathrm{pH}$ (in cave) & 8.15 & 7.9 & & & 8.21 & 8.10 \\
\hline $\begin{array}{l}\text { Electric conductance } \\
(\mu \mathrm{S} / \mathrm{cm})\end{array}$ & 233.50 & 390 & & & 216 & 201.00 \\
\hline Redox Potential (mV) & 231.50 & 220 & 220.00 & 236 & & \\
\hline $\mathrm{pH}$ (laboratory) & 7.98 & 7.8 & 7.45 & 7.87 & 8.0 & 8.10 \\
\hline $\begin{array}{l}\text { Electric conductance } \\
(\mu \mathrm{S} / \mathrm{cm})\end{array}$ & 210.50 & 339 & 175.30 & 315 & 194.7 & 201.00 \\
\hline Total hardness $\left({ }^{\circ} \mathrm{F}\right)$ & 11.48 & 11.15 & 9.53 & 18.3 & 10.1 & 11.90 \\
\hline Bicarbonate (mg/L) & 149.27 & 107.55 & 124.89 & 228.8 & 137.0 & 136.00 \\
\hline Carbonate (mg/L) & absent & absent & absent & absent & absent & absent \\
\hline Silica $\left(\mathrm{SiO}_{2}\right)$ & not detected & not detectable & not detected & not detectable & not detected & 1.40 \\
\hline Water $\mathrm{NH}_{4}^{+}(\mathrm{mg} / \mathrm{L})$ & 0.13 & $<0.01$ & $<0.01$ & $<0.01$ & $<0.05$ & $<0.05$ \\
\hline Water $\mathrm{PO}_{4}^{3-}(\mathrm{mg} / \mathrm{L})$ & 0.10 & $<0.05$ & $<0.05$ & $<0.05$ & $<0.05$ & $<0.05$ \\
\hline Water $\mathrm{NO}_{2}^{-}(\mathrm{mg} / \mathrm{L})$ & 0.15 & $<0.05$ & $<0.05$ & $<0.01$ & $<0.05$ & $<0.05$ \\
\hline Water $\mathrm{Cl}^{-}(\mathrm{mg} / \mathrm{L})$ & 0.83 & 47.15 & 1.27 & 2.7 & 0.80 & 0.60 \\
\hline Water $\mathrm{NO}_{3}^{-}(\mathrm{mg} / \mathrm{L})$ & 3.18 & 6.1 & 2.43 & 0.9 & 5.60 & 2.80 \\
\hline Water $\mathrm{SO}_{4}^{2-}(\mathrm{mg} / \mathrm{L})$ & 2.58 & 2.55 & 1.37 & 2.9 & 1.80 & 2.20 \\
\hline Water $\mathrm{Na}^{+}(\mathrm{mg} / \mathrm{L})$ & 0.35 & 19.5 & 0.73 & 2 & 0.60 & 0.50 \\
\hline Water $\mathrm{K}^{+}(\mathrm{mg} / \mathrm{L})$ & 0.03 & 0.35 & 0.20 & 0.4 & $<0.1$ & $<0.1$ \\
\hline Water $\mathrm{Mg}^{2+}(\mathrm{mg} / \mathrm{L})$ & 0.45 & 0.5 & 0.23 & 19.8 & 1.6 & 0.50 \\
\hline Water $\mathrm{Ca}^{2+}(\mathrm{mg} / \mathrm{L})$ & 45.50 & 43.8 & 37.77 & 40.7 & 37.8 & 46.80 \\
\hline Water $\mathrm{F}^{-}(\mathrm{mg} / \mathrm{L})$ & not detected & not detected & not detectable & not detectable & not detectable & $<0.1$ \\
\hline Iron $\left(\mathrm{Fe}^{3+} \mu \mathrm{g} / \mathrm{L}\right)$ & 5.45 & not detected & not detected & 17 & not detected & not detectable \\
\hline Manganese $\left(\mathrm{Mn}^{2+} \mu \mathrm{g} / \mathrm{L}\right)$ & 0.19 & not detected & not detected & 3.95 & not detected & not detectable \\
\hline Strontium $\left(\mathrm{Sr}^{3+} \mu \mathrm{g} / \mathrm{L}\right)$ & 21.78 & not detected & not detected & 40 & not detected & not detectable \\
\hline Barium $\left(\mathrm{Ba}^{3+} \mu \mathrm{g} / \mathrm{L}\right)$ & 17.60 & not detected & not detected & 4.46 & not detected & not detectable \\
\hline lodine $\left(I^{-} \mu \mathrm{g} / \mathrm{L}\right)$ & not detected & not detected & not detected & $<0.05$ & not detected & not detectable \\
\hline Aluminum $\left(\mathrm{Al}^{3+} \mu \mathrm{g} / \mathrm{L}\right)$ & 14.11 & not detected & not detected & 732.9 & not detected & not detectable \\
\hline
\end{tabular}

for about 20 minutes, moving only for a few $\mathrm{cm}$. Of the three individuals, none was seen with fully submersed whole body; only their heads were underwater. The three individuals were also not seen scraping the rocky surface, with their mouthparts in contact with the substrate. No preening activity was observed in H. asamo.
MOUTHPART AND TARSAL MORPHOLOGY In C. servadeii, mandibles have a characteristic asymmetric shape (Fig. 3) that is clearly distinct from a typical (i.e., non-hygropetric) Leptodirini beetle, such as Orostygia pretneri Müller, 1931 (Fig. 4).

Mandibles in all Hadesia species are symmetric and have more teeth (Fig. 5), especially when compared to $C$. 
Tab. 2: 24-hour behaviour and movement activities of Cansiliella servadeii in the cave Grotta della Foos. Activities are annotated as: $A T$, trophic activity; S, site movement; PZ, cleaning of legs (and antennae); $O$, other activities; I, interaction with other individuals; IW, activity performed in water; $O W$, activity performed out of water.

\begin{tabular}{|c|c|c|c|c|}
\hline Individual; sex & Observer & Date (2010) & Time & Behaviour and notes \\
\hline $\begin{array}{l}\mathrm{C}_{\text {; }} \\
\text { indeterminate }\end{array}$ & Simonutti & 13.06 & $\begin{array}{l}\text { 00:40-01:08 } \\
(28 \mathrm{~min})\end{array}$ & AT: $21 \%$ (100 \% IW); PZ: 25\% (100\% IW); S: $54 \%$ (100 \% IW) \\
\hline D; female & $\begin{array}{l}\text { Dorigo, } \\
\text { Simonutti }\end{array}$ & $12-13.06$ & $\begin{array}{l}17: 30-04: 17 \\
(515 \mathrm{~min})\end{array}$ & $\begin{array}{l}\text { AT: } 23 \% \text { ( } 22 \% \text { IW; } 78 \% \text { OW); PZ: } 33.8 \% \text { (18 \% IW; } 82 \% \text { OW); S: } 39.8 \% \\
\text { (31 \% IW; } 69 \% \text { OW); O: } 2.5 \% \text { (100 \% OW); I: 0.2 \% (100\% OW) } \\
\text { While out of water, beetle floated on a film of water while remaining } \\
\text { anchored to the rock with one claw. Attempt to cross running water } \\
\text { failed due to strong water flow. Touched another animals with its } \\
\text { antennae, followed by immediate turning and changing direction. }\end{array}$ \\
\hline E; female & Dreon & 12.06 & $\begin{array}{l}\text { 17:40-22:05 } \\
(210 \mathrm{~min})\end{array}$ & PZ: $72 \%(100 \%$ OW); S: $28 \%$ (100 \% OW) \\
\hline G; male & Dreon & 12.06 & $\begin{array}{l}22: 35-23: 23 \\
\text { (48 min) }\end{array}$ & AT: 31 \% (100 \% OW); PZ: $10 \%$ (100 \% OW); S: $59 \%$ (36 \% IW; 64 \% OW \\
\hline $\mathrm{H}$; female & Dorigo & 13.06 & $\begin{array}{l}05: 15-11: 15 \\
(360 \mathrm{~min})\end{array}$ & $\begin{array}{l}\text { AT: } 56.7 \% \text { (14 \% IW; } 86 \% \text { OW); PZ: } 27.2 \% \text { (10\% IW; } 90 \% \text { OW); } \\
\text { S: } 15.8 \% \text { (63\% IW; } 37 \% \text { OW); O: } 0.3 \% 100 \% \text { OW) }\end{array}$ \\
\hline $\begin{array}{l}\text { M; } \\
\text { indeterminate }\end{array}$ & Dreon & 13.06 & $\begin{array}{l}05: 15-06: 53 \\
(70 \mathrm{~min})\end{array}$ & $\begin{array}{l}\text { AT: } 23 \%(62,5 \% \text { IW; } 37,5 \% \text { OW); PZ: } 64 \%(100 \% \text { OW); } \\
\text { S: } 13 \%(100 \% \text { OW) }\end{array}$ \\
\hline $\begin{array}{l}\mathrm{N} ; \\
\text { indeterminate }\end{array}$ & Concina & 13.06 & $\begin{array}{l}05: 23-11: 15 \\
(352 \mathrm{~min})\end{array}$ & $\begin{array}{l}\text { AT: } 91 \% \text { ( } 97 \% \text { IW; } 3 \% \text { OW); S: } 9 \%(100 \% \text { IW) } \\
\text { For a few minutes, this beetle was a few centimetres away from } \\
\text { another individual, but ignored it. }\end{array}$ \\
\hline V; female & Dreon & 13.06 & $\begin{array}{l}\text { 07:00-11:15 } \\
\text { (243 min) }\end{array}$ & AT: $12 \%$ (100 \% IW); PZ: $78 \%$ (100 \% IW); S: $24 \%$ (100 \% IW) \\
\hline
\end{tabular}

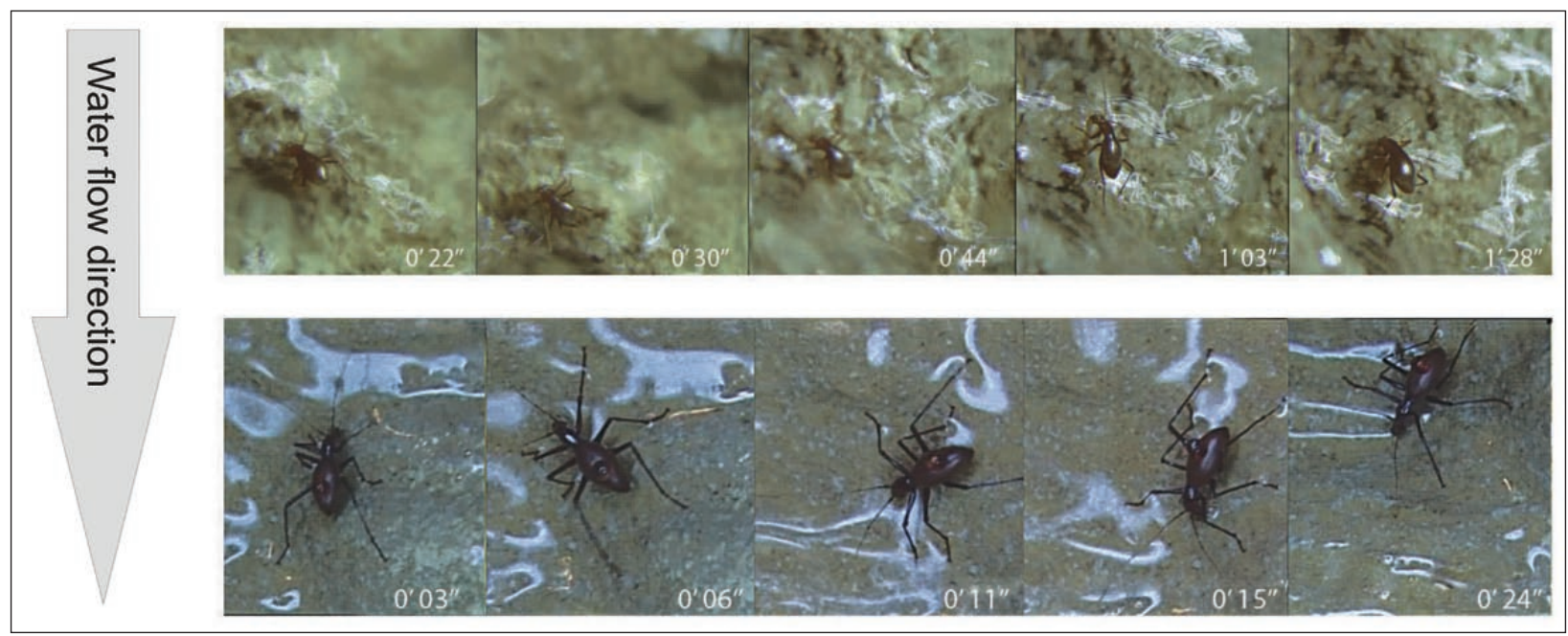

Fig. 2: Cansiliella servadeii (top row) and Hadesia asamo (bottom row) exhibit different behaviours while moving on the hygropetric surface. Specifically, C. servadeii moves in all directions, also with its body perpendicular to the water flow, but H. asamo keeps its body parallel to the water flow, with the keel-shaped abdomen facing upwards (Upper photo: A. Pamio, lower photo: M. Perreau).

servadeii mandibles (Fig. 7: panels 4-9). Differences between the two genera can also be seen from their mouthpart setal pattern; while dorsal side of galeae are covered by long and filamentous setae in Hadesia (Fig. 6), short spines sorted in dense rows are present in C. servadeii (Fig. 7: panel 3 with permission from Paoletti et al. 2011).
In Cansiliella, different degrees of wear, likely due to abrasion, are seen on the mandibular apex (Fig. 7: panels 4-9), but abrasion is not present in Hadesia. Furthermore, the mouthparts of $H$. asamo and $H$. weiratheri show no presence of debris, which contrasts Cansiliella (Fig. 7, with permission from Paoletti et al. 2011). 


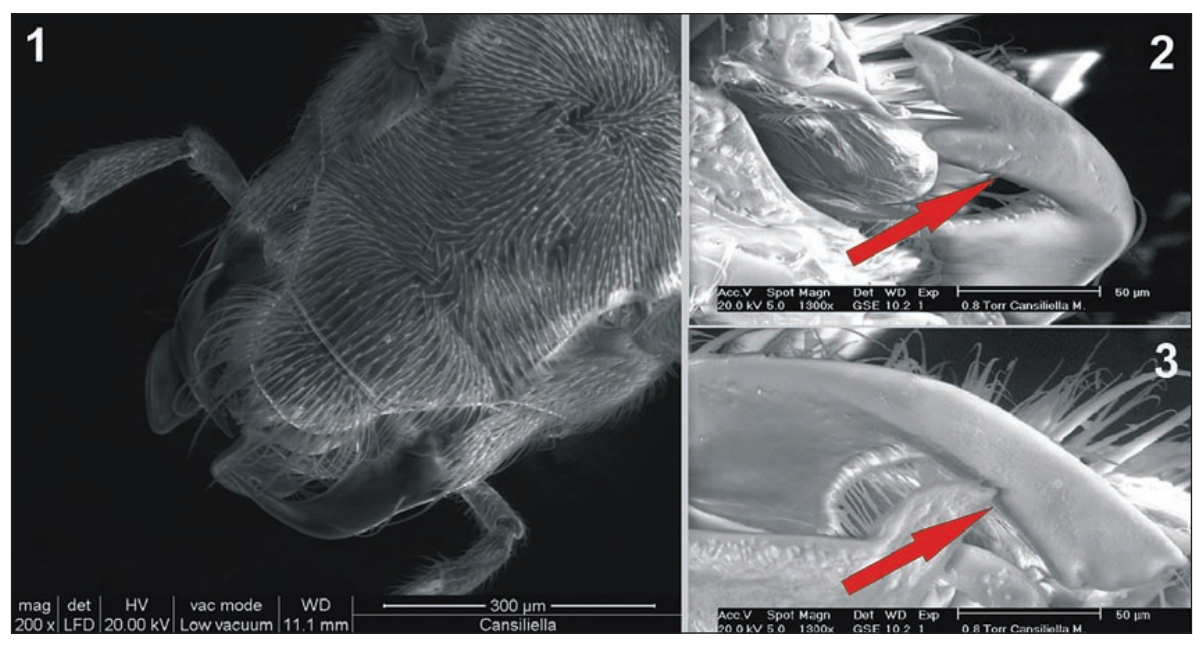

Fig. 3: Cansiliella servadeii: mouthparts, in dorsal view (1); left (2) and right (3) mandibles (Photo 1: E. Ruzzier, photos 2 \& 3: M. Beggio).
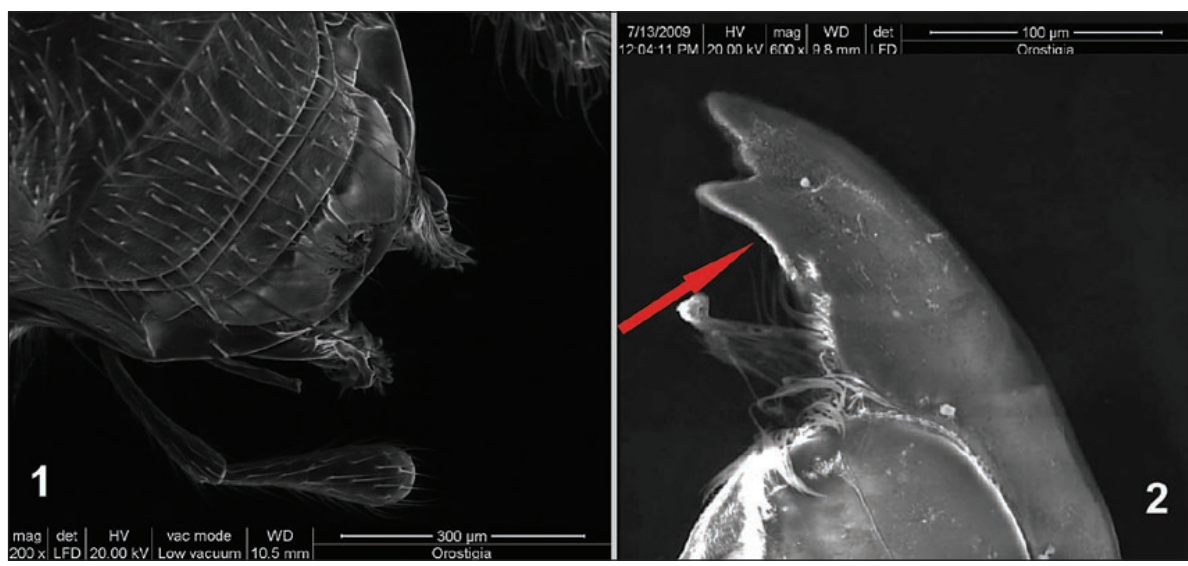

Fig. 4: Orostygia pretneri: mouthparts, in dorsal view (1); right mandible (2). Beetle was collected in the cave Grotta della Foos, near the entrance. (Photo 1: E. Ruzzier, photos 2 \& 3: M. Beggio).

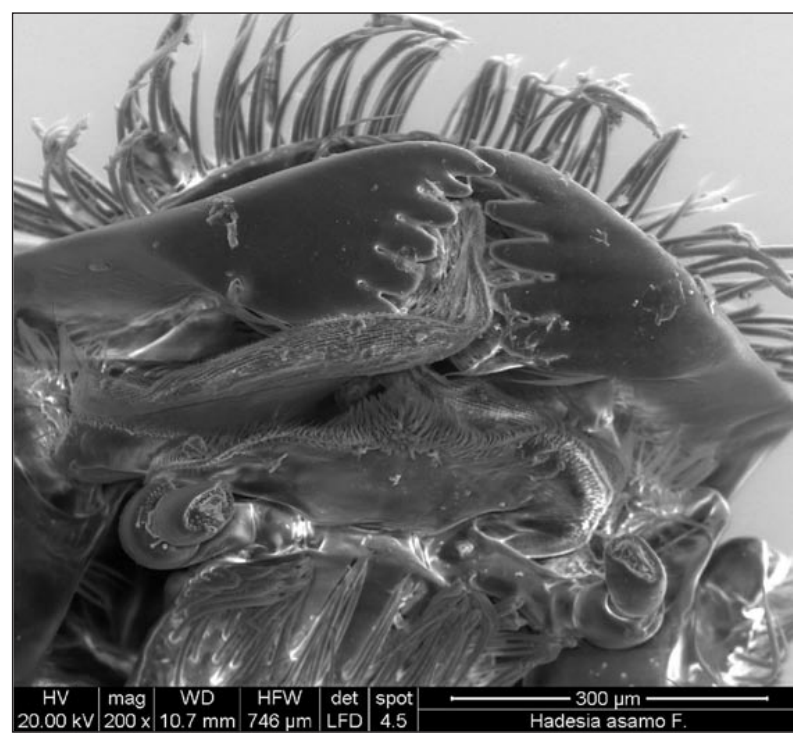

Fig. 5: Mouthparts of Hadesia asamo (Photo: by E. Ruzzier).

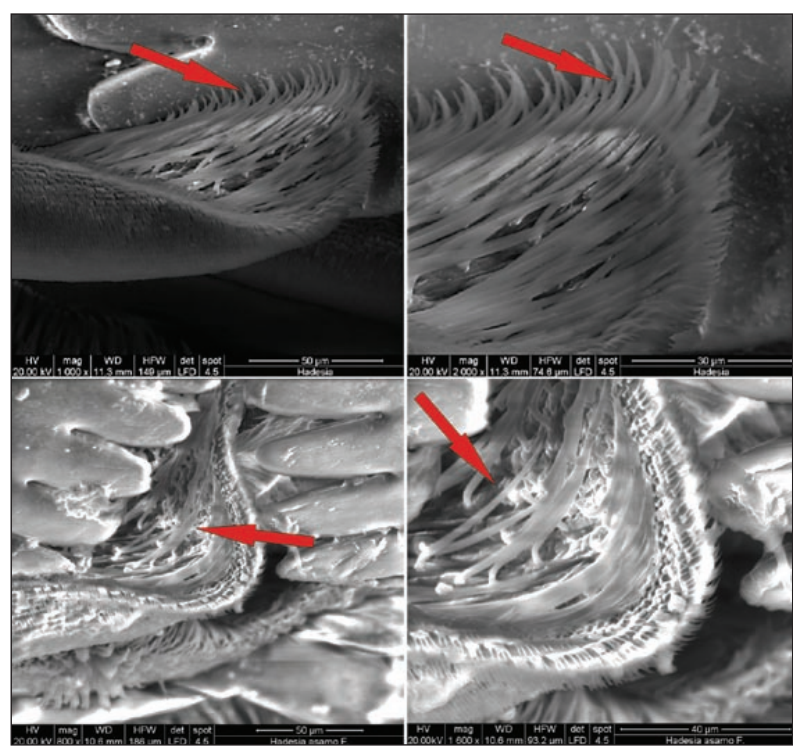

Fig. 6: Mouthparts of Hadesia asamo, dorsal setation of the galeae consisting of long setae. Upper row: $H$. weiratheri, male. Lower row: H. asamo, female (Photo: E. Ruzzier). 

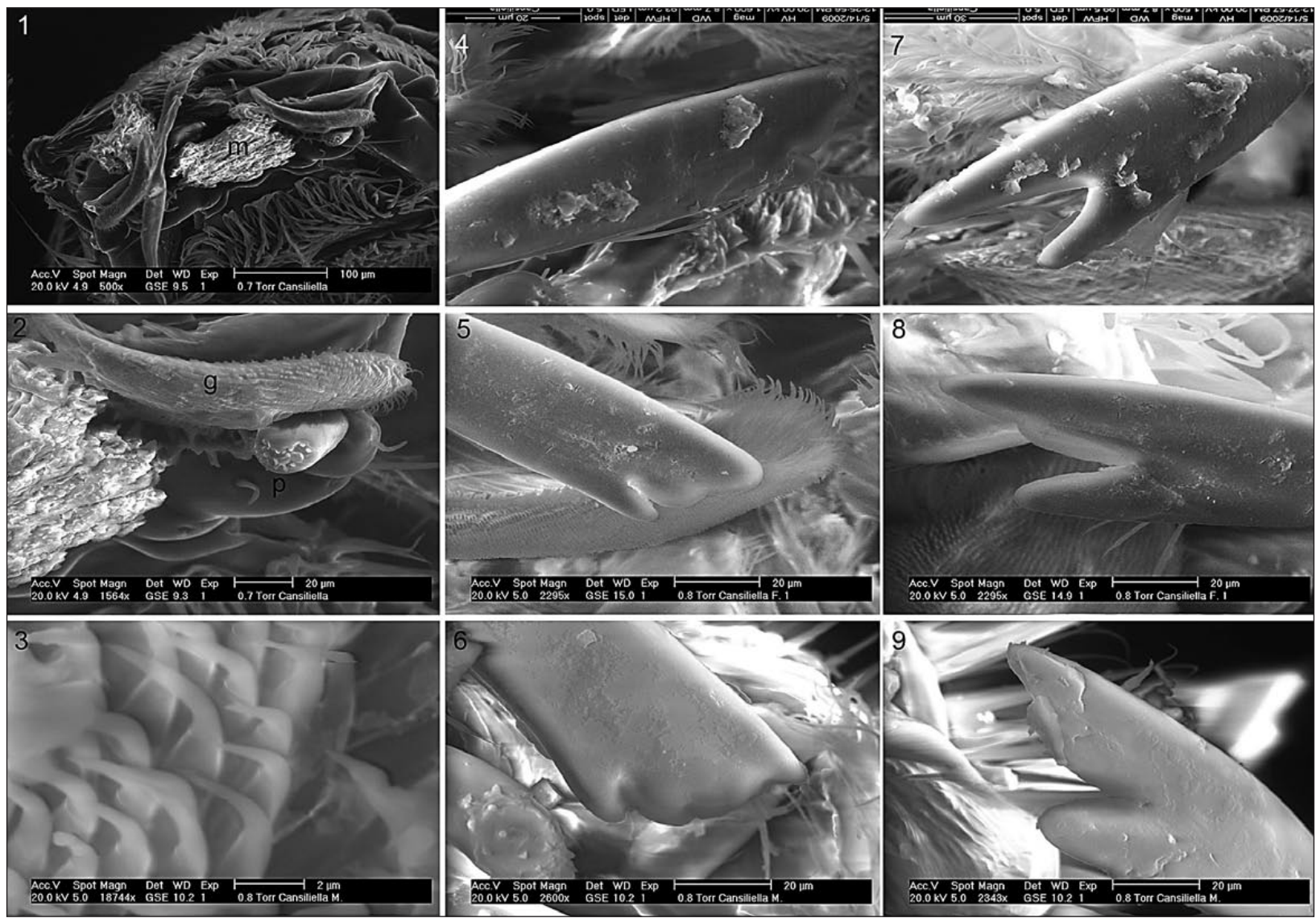

Fig. 7: Hoe-shaped mandibles, spoon-shaped galeae, and labial palps of Cansiliella servadeii.1, a moonmilk particle $(m)$ is visible within mouthparts; 2, magnified view of labial palp (p), left galea (g) and 3, galea setation. 4-6, 3-dentate right mandibles and 7-9, left mandibles. Different degree of apical abrasion, caused by scraping of the substrate, is visible (Photos1 and 3: Paoletti et al., 2011; other photos: M. Beggio).

Tarsi (pro-, meso- and metatarsus) of H. asamo and H. weiratheri have characteristically shaped setae, i.e., bent-blade bristles, that are up to $300 \mu \mathrm{m}$ long and pres-
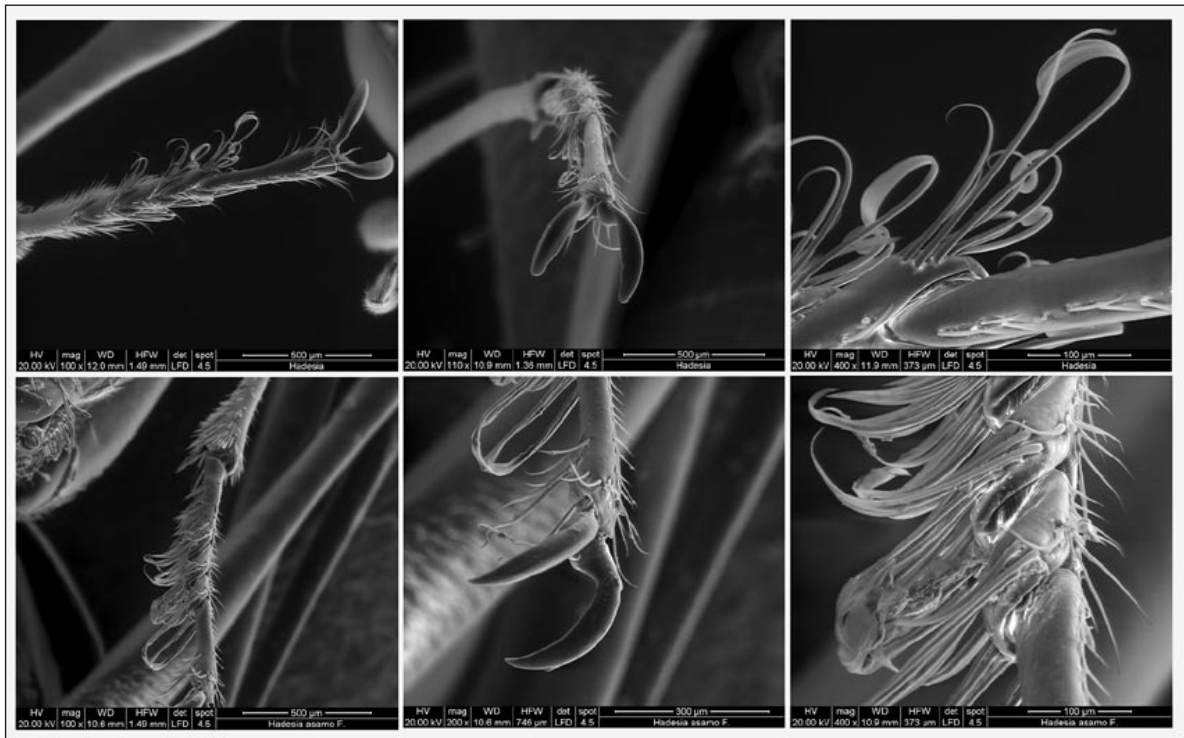

ent on the lateroventral surface of tarsomeres 2-3-4, of both males and females (Fig. 8).

Fig. 8: Tarsi of Hadesia spp. with characteristic bent-blade bristles, more prominent on the right side. Upper row: $H$. weiratheri, male. Lower row: H. asamo, female (Photo: E. Ruzzier). 


\section{DISCUSSION}

During the observation period Cansiliella servadeii and Hadesia asamo displayed different strategies of moving in water flow and in feeding behaviour. C. servadeii moved trough the running water, completely submerged and protected by an air bubble, movements were irregular and in all possible directions. H. asamo, however, was never completely submerged but merely lapped by the flowing water surface; when entering the water film, this species oriented its abdomen upstream, facing the water flow, and then moved laterally.

Also morphological comparison between the mouthparts of both species showed important dissimilarities. It is uncertain whether mouthpart structural differences between C. servadeii and H. asamo are related to their different trophic habits. In C. servadeii, pieces of moonmilk between the mandibles had previously been observed by using SEM; the different degrees of mandibular abrasion were interpreted as a result of the browsing of moonmilk and the shape and distance of $(1-1.5 \mu \mathrm{m})$ the upper galeae spines, as the means for brushing bacteria (Fig. 7; Paoletti et al. 2011). Nothing of the kind was noticed in Hadesia. Moreover, the presence of long bristles on the dorsal galeae suggests that $H$. asamo and $H$. weiratheri may perform water filtration rather than scraping of rock surfaces like C. servadeii.

The above listed differences possibly indicate that C. servadeii interacts with the moonmilk surface while H. asamo, and probably also its congeners, interact exclusively with the water film. It may be possible that the evolution of two different feeding behaviours was promoted by different body sizes of both genera. C. servadeii is small and able to move freely inside the water by creating a bubble of air; a reduced body size combined with the air bubble probably help the animal to easier resist the water flow, allowing a free set of movements in the water film. In contrast, $H$. asamo is larger and potentially more subjected to water flow; consequently the particular movement strategy may help prevent its drowning. Furthermore the orientation of the elytra apex against the water flow could help breaking the flow, thereby decreasing the body's resistance against it. Anchorage to the substrate by $H$. asamo and probably by other species of this genus may likely be facilitated not only through long claws, but also by characteristic bent-blade bristles, present on the ventral surface of tarsi. These bristles are present also in $H$. weiratheri (Fig. 8) and in H. zetae (Polak et al. 2016), as well as in some other Leptodirini. However, they have been observed neither in Cansiliella (Paoletti et al. 2013: Fig. 2b), nor in other tribes of Cholevinae for which the structure of tarsi have been investigated in detail (Antunes-Carvalho \& Gnaspini 2015). The true function of the bristles has not yet been verified and must be tested.

In C. servadeii the most commonly observed in situ behaviours were trophic and preening activities. In particular, C. servadeii dedicated $36 \%$ of its time to preening while in $H$. asamo such behaviour has never been observed. Self-preening activity in insects is a multipurpose behaviour whose functions could range from the collection of food (Rath 1999), removal of objects or material from the body surface, including parasites (Peng et al. 1987; Božič \& Valentinčič 1995), distribution of substances across the body surface, as a displacement behaviour in stressful conditions (Howse 1974; Golenda \& Forgash 1986), grooming of tarsi to maintain adhesion of attachment pads (Hosoda \& Gorb 2011), or spontaneous action with no apparent external stimuli (Spruijt et al. 1992). Preening activity can be performed in different forms, such as by using mouthparts to remove material or parasites (e.g., in Orthoptera and Coleoptera) or by depositing debris onto a substrate (e.g., in Diptera and Lepidoptera) (Zhukovskaya et al. 2013). Debris can be either manipulated into the hypopharynx and ingested (Robinson 1996) or not (Božič \& Valentinčič 1995).

We hypothesize that preening in Cansiliella is connected with trophic activity because, to date, parasites have not been observed in the moonmilk or biofilm above the moonmilk (Engel et al. 2013; Paoletti et al. 2013), and all individuals were observed in situ, under natural conditions and free of stress sources. Moreover, as abundant microbial cells have been observed on Cansiliella appendages (Paoletti et al. 2011, 2013) we consider plausible that microorganisms picked up during browsing are thereby removed from legs and antennae. This could suggest that preening behaviour is closely connected with the trophic activity and potentially related to animal-bacterial symbioses. Another plausible hypothesis is that the action of brushing antennae could have the function of keeping the sensory appendages clean (Böröczky et al. 2013). In Leptodirini this function may be important to ensure the functionality of hygroreceptors (Hamann's organ), which are fundamental devices for finding wet habitats (Lucarelli \& Sbordoni 1977).

The fact that preening has not been observed in Hadesia asamo so far - despite comparable observation conditions - seems to disregard the latter hypothesis and suggest that for Hadesia this activity is not as relevant as it is for C. servadeii. 


\section{CONCLUSIONS}

An evaluation of behavioural activities and morphological features of two Leptodirini beetles living in hygropetric habitats, Hadesia asamo and Cansiliella servadeii, revealed distinct differences in their feeding, movement, and preening activities. At the same, time differences in the microstructure of the mouthparts were discovered, specifically in the presence and configuration of the specialised setae on the galeae. Together with the observed differences in the foraging behaviour, these results suggest that these hygropetricolous beetles have the ability to exploit different resources in their habitat, which potentially emphasizes the ecological principle of finding "a niche within a niche." Body size may influence the way of beetle movement in the semi-aquatic habitat, likely affecting also their feeding strategies.
The observed differences suggest that Cansiliella interacts with the moonmilk surface while Hadesia interacts with the water film, not with the rock surface. To date, the association of C. servadeii with a moonmilk habitat still represent a peculiar animal-bacterial system.

Additional behavioural observations of other Leptodirini with "hadesian habits" are needed to improve the knowledge of the activities, feeding patterns, and other trophic associations in hygropetricolous beetles. More research on the physicochemistry, organic carbon concentrations, and overall nutrient conditions of hygropetric habitats is also needed, serving as a basis for understanding how these habitats fit into the overall cave ecosystem and how resources are used by the cave fauna.

\section{ACKNOWLEDGEMENTS}

We thank all members of the "Gruppo Speleologico Pradis" and members of the "Circolo Speleologico Idrologico Friulano "(CSIF) for their help during in cave field activities in Italy. We also thank the speleologists of Zelena Brda speleological group in Trebinje for their collaboration for field work in Bosnia and Herzegovina. The research and previous manuscript drafts benefited from ideas and contributions from R. Caicci, O. Coppellotti, L. Deharveng, A. Faille, B. Jalžić, L. Latella, R. Mazzaro, O. Moldovan, M. Simonetti, U. Sauro, M. Schilthuizen and B. Sket.

We thank two anonymous referees for their valuable comments and suggestions.

\section{REFERENCES}

Antunes-Carvalho, C. \& P. Gnaspini, 2015: Pretarsus and distal margin of the terminal tarsomere as an unexplored character system for higher-level classification in Cholevinae (Coleoptera, Leiodidae).- Systematic Entomology, 41, 2, 392-415. DOI: https:// doi.org/10.1111/syen.12161.

APHA, 2012: Standard Methods for examination of water and wastewater, $22^{\text {nd }}$ ed.- American Public Health Association, pp. 1360, Washington.

Böröczky, K., Wada-Katsumata, A., Batchelor, D., Zhukovskaya, M. \& C. Schal, 2013: Insects groom their antennae to enhance olfactory acuity.- Proceedings of the National Academy of Science (United States of America), 110, 9, 3615-3620. DOI: https://doi. org/10.1073/pnas.1212466110.
Božič, J. \& T. Valentinčič, 1995: Quantitative analysis of social grooming behavior of the honey bee Apis mellifera carnica.- Apidologie, 26, 2, 141-147. DOI : https://doi.org/10.1051/apido:19950207.

Casale, A. \& B. Jalžić, 1988: Radziella (new genus) styx n. sp., a new exceptional troglobitic Bathysciinae (Coleoptera, Catopidae) from the Dinaric region, Jugoslavia.- Bollettino Museo Regionale di Scienze Naturali, Torino, 6, 2, 349-358.

Casale, A., Carcupino, M. \& P.M. Giachino, 2000a. Ultrastructure of filtering mouth parts in highly specialized troglobitic Leptodirinae (Coleoptera, Cholevidae).- In: D.L. Gazzoni (ed.) Proc. XXI International Congress of Entomology, $20^{\text {th }}-26^{\text {th }}$ August 2000, Foz do Iguaçu, Brazil. Embrapa Soja, 936, Londrina, Brazil. 
Casale, A., Giachino, P.M. \& B. Jalžić, 2000b: Croatodirus (nov. gen.) bozicevici n. sp., an enigmatic new Leptodirine beetle from Croatia (Coleoptera, Cholevidae).- Natura Croatica, 9, 2, 83-92.

Casale, A., Giachino, P.M. \& B. Jalžić, 2004: Three new species and one new genus of ultraspecialized cave dwelling Leptodirinae from Croatia.- Natura Croatica, 13, 4, 301-317.

Culver, D.C., 1982: Cave Life, Evolution and Ecology.Harvard University Press, pp. 189, Cambridge.

Engel, A.S., Paoletti, M.G., Beggio, M., Dorigo, L., Pamio, A., Gomiero, T., Furlan, C., Brilli, M., Bertoni, B. \& A.L. Dreon, 2013: Comparative microbial community composition from secondary carbonate (moonmilk) deposits: implications for the Cansiliella servadeii cave hygropetric food web.- International Journal of Speleology, 42, 3, 181-192. DOI: https://doi.org/10.5038/1827-806X.42.3.2.

Gasparo, F., 1971: La grotta della Foos presso Campone (Prealpi Carniche).- Mondo Sotterraneo, 1, 37-52.

Giachino, P.M. \& D. Vailati, 2006: Kircheria beroni, a new genus and new species of subterranean hygropetricolous Leptodirinae from Albania (Coleoptera, Cholevidae).- Subterranean Biology, 4, 103-116.

Golenda, C.F. \& A.J. Forgash, 1986: Grooming behavior in response to fenvalerate treatment in pyrethroidresistant house flies.- Entomologia Experimentalis et Applicata, 40, 2, 169-175. DOI: https://doi. org/10.1111/j.1570-7458.1986.tb00499.x.

Hill, C.A. \& P. Forti, 1997: Cave Minerals of the World.National Speleological Society, pp. 446, Huntsville, Alabama.

Hosoda, N. \& S.N. Gorb, 2011: Friction force reduction triggers feet grooming behaviour in beetles.- Proceedings of the Royal Society B, 278, 1712, 1748-1752. DOI: https://dx.doi.org/10.1098/ rspb.2010.1772.

Kane, T.C. \& T.L. Poulson, 1976: Foraging by cave beetles: spatial and temporal heterogeneity of prey.Ecology, 57, 4, 793-800. DOI: https://dx.doi. org/10.2307/1936192.

Lamprecht, G. \& F. Weber, 1992: Spontaneous locomotion behaviour in cavernicolous animals: the regression of the endogenous circadian system.- In: Camacho, A.I. (ed.) The Natural History in Biospeleology. Museo Nactional de Ciencias Naturales, pp. 225-262, Madrid.

Lohaj, R., Ceplik, D., Mlejnek, R \& J. Lakota, 2012: A new species of the genus Nauticiella Moravec and Mlejnek from southern Herzegovina (Coleoptera: Leiodidae: Leptodirini).- Fauna Balkana, 1, 177-187.
Lucarelli, M. \& V. Sbordoni, 1977: Humidity responses and the role of Hamann's organ of cavernicolous Bathysciinae (Coleoptera Catopidae).- International Journal of Speleology, 9, 2, 167-177. DOI: https:// doi.org/10.5038/1827-806X.9.2.9.

Moldovan, O.T., Jalžić, B. \& E. Erichsen, 2004: Adaptation of the mouthparts in some subterranean Cholevinae (Coleoptera, Leiodidae).- Natura Croatica, 13, 1-18.

Moravec, J. \& R. Mlejnek, 2002: Nauticiella stygivaga gen.n. et sp. n., a new amphibiontic cavernicolous beetle from the Vjetrenica Cave, Herzegovina (Coleoptera: Leiodidae: Cholevinae: Leptodirini).- Acta Societatis Zoolocicae Bohemicae, 66, 293-302.

Nonveiller, G. \& D. Pavićević, 1999: Tartariella durmitorensis $\mathrm{n}$. gen. et $\mathrm{n}$. sp. troisième Leptodirini de la chaîne dinarique à moeurs hadésiennes (Coleoptera, Leiodidae).- Bulletin de la Société Entomologique de France, 104, 315-326.

Paoletti, M.G., 1972: Un nuovo Catopide pholeuonoide del Cansiglio (Prealpi Carniche).- Bollettino $\mathrm{Mu}$ seo Civico di Storia Naturale di Venezia, 22-23, 119-131.

Paoletti, M.G., 1973: Notizie sistematiche ed ecologiche su di un nuovo interessante genere del Cansiglio: Cansiliella.- Suppl. Bollettino Museo Civico di Storia Naturale di Venezia, 24, 81-88.

Paoletti, M.G., 1980: Dati aggiuntivi alla conoscenza del genere Cansiliella Paoletti (Col. Bathysciinae).- Redia, 63, 67-80.

Paoletti, M.G., Beggio, M., Dreon, A.L., Pamio, A., Gomiero, T., Brilli, M., Dorigo, L., Concheri, G., Squartini, A. \& A.S. Engel, 2011: A new foodweb based on bacteria in calcitic caves: The Cansiliella case (beetles Leptodirinae) in northern Italy.- International Journal of Speleology, 40, 1, 45-52. DOI: https:// doi.org/10.5038/1827-806X.40.1.6.

Paoletti, M.G., Dreon, A.L., Dorigo, L., Beggio, M., Pamio, A., Concina, G., Simonutti, V., Toniello, V., Brilli, M., Concheri, G. \& A. Squartini, 2012: Una nuova catena alimentare basata sui batteri del moonmilk? Ricerche su Cansiliella servadeii, un coleottero troglobio del Monte Cjaurlec. In: AAVV Tra rocce, fauna e storia. Attività e ricerche del Gruppo Speleologico Pradis 2006/2011, Pordenone. 
Paoletti, M.G., Mazzon, L., Martinez Sanudo, I., Simonato, M., Beggio, M., Dreon, A.L., Pamio, A., Gomiero, T., Brilli, M., Dorigo, L., Engel, A.S., Baldan, B., Tondello, A., Concheri, G. \& A. Squartini, 2013: A unique midgut-associated bacterial community hosted by the endemic cave beetle Cansiliella servadeii (Coleoptera: Leptodirini) reveals parallel phylogenetic divergences from universal gut-specific ancestors. BMC Microbiology, 13, 129. https://doi. org/10.1186/1471-2180-13-129.

Peng, Y.S., Fang, Y., Xu, S., Ge, L., \& M.E. Nasr, 1987: The resistance mechanism of the Asian honey bee, Apis cerana Fabr, to an ectoparasitic mite Varroa jacobsoni Oudemans.- Journal of Invertebrate Pathology, 49, 1, 54-60. DOI: https://doi.org/10.1016/00222011(87)90125-X.

Perreau, M. \& D. Pavićević, 2008: The genus Hadesia Müller, 1911 and the phylogeny of Anthroherponina (Coleoptera, Leiodidae, Cholevinae, Leptodirini).- In: Pavićević, D. \& M. Perreau (eds.) Advances in the Studies of the Fauna of the Balkan Peninsula. Monographs, 22, Institute for Nature Conservation of Serbia, 215-239, Belgrade.

Polak, S., Delić T., Kostanjsek, R. \& P. Trontelj, 2016: Molecular phylogeny of the cave beetle genus Hadesia (Coleoptera: Leiodidae: Cholevinae: Leptodirini), with a description of a new species from Montenegro.- Arthropod Systematics and Phylogeny, 7412, 3, 241-254.
Rath, W., 1999: Co-adaptation of Apis cerana Fabr and Varroa jacobsoni Oud.- Apidologie, 30, 2-3, 97-110. DOI: https://doi.org/10.1051/apido:19990202.

Rétaux, S. \& Y. Elipota, 2013: Feed or fight: A behavioral shift in blind cavefish.- Communicative \& Integrative Biology, 6, 2, 1-10. DOI: https://doi. org/10.4161/cib.23166.

Remy, P., 1940: Sur le mode de vie des Hadesia dans la grotte Vjetrenica (col. Bathysciinae).- Revue Française d'Entomologie, 7, 1-8.

Robinson, W.H., 1996: Antennal grooming and movement behaviour in the German Cockroach, Blattella germanica (L.).- In: Wildey, K.B. (ed.) Proceedings of the Second International Conference on Urban Pests, $7^{\text {th }}-10^{\text {th }}$ July 1996, Edinburgh, ICUP, 361-369, Edinburgh, UK.

Sket B., 1979: Higropetrik v jamah.- Proteus, 41, 8, 312 313.

Sket, B., 2004: The cave hygropetric - a little known habitat and its inhabitants.- Archiv für Hydrobiologie, 160, 413-425. DOI: https://doi.org/10.1127/00039136/2004/0160-0413.

Spruijt, B., van Hooff, J. \& W. Gispen, 1992: Ethology and neurobiology of grooming behavior.- Physiological Reviews, 72, 3, 825-852.

Zhukovskaya, M., Yanagawa, A. \& B.T. Forschler, 2013: Grooming behavior as a mechanism of insect disease defense.- Insects, 4, 4, 609-630. DOI: https:// doi.org/10.3390/insects4040609. 